\title{
NUP98/HOXD13 Fusion Gene
}

National Cancer Institute

\section{Source}

National Cancer Institute. NUP98/HOXD13 Fusion Gene. NCI Thesaurus. Code C99447.

A fusion gene $(\sim 1.9 \mathrm{~kb})$ that results from a chromosomal translocation $\mathrm{t}(2 ; 11)(\mathrm{q} 31 ; \mathrm{p} 15)$

which fuses the first twelve exons of the NUP98 gene with exon 2 of the HOXD13 gene.

This rearrangement is associated with acute myeloid leukemia. 